\title{
THE PROGRESS OF GRASSLAND RESEARCH IN BRITAIN DURING THE LAST DECADE
}

\section{E. K. WOODFORD}

Grassland Research Institute, Hurley, England.

GRASS still occupies about $65 \%$ of the agricultural land of the islands that make up the United Kingdom. The research effort devoted to all aspects of its growth and utilization is considerable and is carried out by many official organizations, by large commercial firms, and by a few farmers. A review of the progress during the last decade, if confined to the limits of a single paper, is in consequence likely to be biased- in the direction of the writer's own interests. I confess at the start that this review is based largely on my experiences at the Grassland Research Institute at Hurley during the last five years and draws freely on the thoughts and recollections of several of my senior colleagues.

In order to set the review in its proper context, it is perhaps advisable to remind this audience of the range of environments in which these grasslands exist and the major changes that have taken place in the last decade in management and utilization.

\section{CLIMATE}

Variations in climate are quite large despite the small area and limited altitudes. In general, rainfall increases from east to west and ranges from about 20 in. to 80 in. per year, with a countrywide average of 30 in. p.i. Variations in temperature associated with changes in latitude and altitude also have a marked effect on the nature and duration of the growth of grass. The length of the grazing season in sown pastures varies from about 39 weeks in the southwest to 27 weeks or less in the north.

\section{LAND USE}

The records of agricultural statistics in England are extensive and date back to the great Domesday Survey of 1085. Annual records were, however, not started until 1866 and the rise and fall in the acreages of "permanent" 
and "temporary" grass during the last hundred years are an interesting reflection of the political and economic changes that have taken place since the "Golden Age" of British farming, when the total arable acreage was about the same as it is at the present time. Since the rnajor upheavals brought about by the Second World War, when $37.5 \%$ of the permanent grass was ploughed, changes in land use have been less spectacular but significant. The reduction in the acreage of permanent grass, rough grazing and rotational grass and clover since 1955 has been gradual and accompanied by a corresponding increase in the acreage of cereals, particularly barley. This change from grass to barley has taken place throughout the country but has been most spectacular in the eastern drier areas, in many parts of which the acreage of sown grass has been halved during the last 10 years.

\section{SEEDS MIXTURES}

Associated with the decrease in the acreage of temporary grass there has also been an awakening of interest by the farmer in the differences between species and varieties and in the advantages of single species swards. This has been brought about largely by the detailed assessment of yield and digestibility of the many varieties that are evaluated by the National Institute of Agricultural Botany. This organization now publishes recommended varieties of grasses and herbage legumes. The biggest change has been the drop in the acreage of cocksfoot, owing to its low digestibility, and the increase in popularity of ryegrass (Table 1).

TABLE 1: GRASS SEED SOLD 'IN U.K. $(1,000 \mathrm{cwt})$

\begin{tabular}{|c|c|c|c|}
\hline & 1960-1 & $1964-5$ & $1966-7$ \\
\hline Perennial ryegrass & 242 & 273 & 241 \\
\hline Italian ryegrass & 142 & 155 & 136 \\
\hline Cocksfoot & 55 & 39 & 27 \\
\hline Timothy & 57 & 44 & 45 \\
\hline Meadow fescue & 24 & 20 & 15 \\
\hline
\end{tabular}

FERTILIZERS

The increase in the average amounts of fertilizers applied to temporary and permanent grassland has shown a steady rise (Table 2). 
GRASSLATND RESËARCH I N BRITAIN

TABLE 2: AVERAGE AMOUNTS OF FERTILIZER USED IN ENGLAND AND WALES

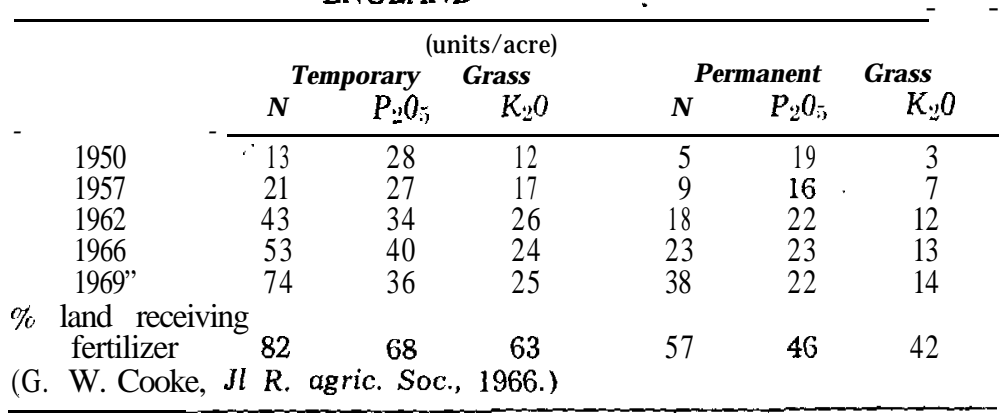

* Provisional.

However, the extent of the increase is small in comparison with the doses recommended. National statistics are not available for the years subsequent to 1966, but it is known, from more limited surveys, that many intensive grassland farmers are using amounts of nitrogen in excess of 300 units per acre. Surveys also show that the profitability of animal enterprises generally increase with the quantity of nitrogen applied up to very high levels. Data (Table 3) from the Milk Marketing Board's survey of farms in their Low Cost Production Scheme (England and Wales) (1970) for the years from 1964 to 1968, show how the average use of nitrogen has been increasing, together with stocking rate and gross margin per acre.

TABLE 3: NITROGEN USE AND PROFITABILITY

\begin{tabular}{lrrrrr}
\hline & 1964 & 1965 & 1966 & 1967 & 1968 \\
\hline Units N/acre & 77 & 80 & 95 & 115 & 131 \\
Stocking rate, acres/cow & 1.68 & 1.58 & 1.46 & 1.40 & 1.30 \\
Gross margin/acre £ & 41 & 53 & 61 & 64 & 69 \\
\hline
\end{tabular}

(Figures from the Milk Marketing Board's survey of farms in the:r Low Cost Production Scheme.)

\section{YIELD AND QUALITY}

The yield of grass in the country as a whole is probably very closely correlated with the amount of nitrogen applied. Average yields are impossible to obtain with any degree of accuracy, but quoted figures (Ashton, 1963) for USE/acre 'show that they rose from 15.2 to 16.0 between $1957-8$ and $1962-3$, and that at present they are only 17.0, although 
the best farmers must be attaining $30 \mathrm{cwt} /$ acre. In recent years much stress has been placed on quality, as measured by digestibility, and farmers are well aware of its importance, particularly when grass is being conserved

\section{CONSERVATION}

Hay is still the most popular method of conserving grass. It is estimated that more than $80 \%$ of all the herbage that is cut is still made into hay despite that, on average, $30 \%$ of the dry matter is lost in the process. Improvements in machinery for cutting, tedding and crimping have helped considerably in field drying and these, together with new machines for chopping and loading, as well as new techniques for making silage using plastic and additives (McDonald et al., 1966) have increased the amount of silage made by about $80 \%$ in the last ten years. Even so, the ensiled grass still accounts for only about $15 \%$ of the total dry matter conserved.

Despite the dependence of hay- and silage-making on weather, use of barn-hay drying methods and of high temperature dehydration is still relatively insignificant. There has been much interest in high temperature tumbler-driers during the last two years, but as there is as yet no assured market for "dried grass" as a feed for ruminant animals, the quantities produced annually are, on a dry-matter basis, less than $1 / 10$. of the silage.

\section{THE FUTURE}

Changes in the acreage of grassland and in the way in which the grass is used in a controlled agricultural economy such as exists in the U.K. are brought about mainly by political decisions implemented at the annual Review and Determination of Guarantees (Anon., 1969). Agricultural research and development provide some of the basic information on which it is assumed that government policy is based. In the U.K., however, the separation of the Agricultural Research Service from the Ministry of Agriculture, Fisheries and Food, by placing it in a separate department of government (Department of Education and Science), effectively makes the channels of communication long and devious, and sometimes almost non-existent.

The present Government has been much more concerned with forward planning than its predecessors, but unfortunately its "National Economic Development Plan," prepared in rather a hurry in 1965, lasted little more than a 
year and is now having to be re-written. More realistic forward estimates of the part that agriculture can play in helping the country's balance of trade by saving imports are being made by the National Economic Development Committee. The first report of the National Economic Development Committee for the Agricultural Industry (1968) has been accepted by the Government as the basis for their selective expansion programme. It calls for the ploughing up and sowing to cereals of 1.6 million acres of grass and for an increased stocking density, on the reduced grassland, of $3 \frac{1}{4} \%$ per annum. This increase in stocking is not much greater than the 2 to $2 \frac{1}{2} \%$ increase that has taken place over the last five years, and could easily be accomplished by farmers if they were given the incentive. Unfortunately, such encouragement has not been forthcoming and practice is not matching prediction. If, however, the U.K. does eventually join the European Economic Community, it is generally agreed that the increased price of cereals which is bound to follow (EEC price for barley is now E36 a ton, as compared with U.K. price of E25) will increase the relative value of grass and grass products.

\section{RESEARCH AND DEVELOPMENT}

The U.K. is well provided with official and industrial research organizations concerned with grassland science and over the past decade these have expanded considerably. Figures are not available for the industrial sector, but the increase on the official side for all agricultural research has been about 10 to $15 \%$. Work on some aspects of grass growth and utilization is undertaken at the Grassland Research Institute; the Hill Farming Research Organization; the Welsh Plant Breeding Station; the Plant Breeding Institute, Cambridge; the Scottish Plant Breeding Institute; the Weed Research Organization; the Hannah Dairy Research Institute; the National Institute for Research in Dairying; the Rowett Research Institute; the National Institute of Agricultural Engineering; the National Institute of Agricultural Botany; in many university departments of agriculture and at the experimental husbandry farms of the National Agricultural Advisory Service. At all of these the amount of work done on grass has increased, but only at a few (G.R.I., W.P.B.S., N.I.A.E.) has it increased at the national average rate for all agricultural research.

During the last decade there has been a move from studies designed to answer the practical problems posed 
by the farmers to the more basic investigations directed to an understanding 'of how grass and forage crops grow and interact with the environment and how they can be preserved and utilized by ruminant animals. This change in the emphasis of research is characteristic of progress in any technology and is illustrated in the reports that follow on the changing pattern of grassland research.

\section{BOTANY}

Looking back at the botanical research carried out in the late fifties and earlier sixties in England, the work of Langer (1956, 1957) still stands out as some of the most important. His penetrating analysis of the growth of single plants of timothy emphasized the importance of the tiller as the basic plant unit and led on to an understanding of perenniality in terms of tiller succession.

At the crop level, Watson $(1952,1968)$ and others extended the classical concepts of growth analysis. This in turn focused attention on light interception and crop geometry and led to the ideas of ceiling and optimum leaf area, and ceiling yield. British grassland botanists were much involved in these developments, and at both Aberystwyth (Pate1 and Cooper, 1961) and Hurley (Ryle, 1967;

Robson, 1967, 1968) workers were using growth analysis extensively to study the effects of the major factors of the environment such as light, temperature and nutrition.

By the middle sixties, however, the limitations of growth analysis were apparent (Anslow, 1966) and new physiological concepts and tools, largely derived from more academic and basic research in other fields, were becoming available. An important discovery, for grass physiologists no less than others, was the finding that some tropical plants used a radically different metabolic pathway for incorporating carbon into sugar from that already well known for temperate plants and algae (Hatch and Slack, 1966; Hatch et al., 1967). This, and associated findings concerning photo-respiration (or photo-decarboxylation as many would have it) have revitalized thinking about photosynthesis and respiration, and at both Hurley and Aberystwyth emphasis has turned from growth analysis to the direct measurement of the flux of carbon in leaves, plants and swards grown in both controlled environments and in the field.

Emphasis has also shifted from descriptive morphology to physiological and biochemical studies aimed at an understanding of the primary component processes which sus- 
tain growth. Thus the effect of environmental and genetical factors are now being thought of in terms of their influence on photosynthesis and respiration and the partitioning of carbon within the plant (Ryle, 1970). At the same time, the descriptive information accumulated over the years on the morphology of the plant and the sward (tiller numbers, rate of tillering, leaf numbers and area, etc.) is proving invaluable for the more sophisticated mathematical treatment of the crop canopy so necessary for an understanding of its response to the environment (de Wit, 1965; Monteith, 1965). Physiologists are also at last beginning to tackle some of the important problems connected with the perenniality of the grass plant and how a tillering species maintains a dynamic. equilibrium with respect to its tiller numbers, by partitioning metabolites within tillers, between new tillers, and between terminal leaf expansion and roots (Ryle, loc. cit.).

As an example of this general pattern of progress from developmental morphology and growth analysis to the more detailed physiological and metabolic studies, I can quote the major changes that took place during the first half of the last decade at the Grassland Research Institute. At the beginning of this period, the main interest was in grazed grass, and botanists, following the lead given by the agronomists, were studying:

(1) The comparative growth and development of the four important crop grasses, ryegrass, cocksfoot, timothy and fescue.

(2) Factors affecting the yield of seed from these species.

(3) The importance of legumes (particularly white clover) when grown in association with grass.

(4) The extension of the growing season to provide early spring and late autumn grazing.

By the mid-sixties, however, the apparent importance of all four topics had changed. Ryegrass had emerged as the most important species; the problems of seed production had been referred back to the plant breeder; cheap nitrogen and fertilizer subsidies had reduced the need for clover, and the severe winter of 1963 had killed off the Mediterranean fescues and other winter-grown swards on which so much hope had been placed, and demonstrated the insuperable difficulty of trying to make grasses grow in the cold and relative darkness of late autumn. Thus the emphasis changed from grazing to cutting and the use of 
single varieties that could make the maximum use of the environment when conditions were most favourable for plant growth. Botanists became more interested in basic studies aimed at an understanding of how forage plants function, how defoliation affects this, and how genotypes compare in the efficiency with which they utilize the environment.

\section{PLANT BREEDING}

British plant breeders have relatively little to show in terms of new grass varieties for all their hard work during the sixties (see Table 4). Much information has, nevertheless, been acquired about the major attributes of plant growth that determine yield and that can be used as selection criteria.

TABLE 4: GRASS AND CLOVER VARIETIES RELEASED IN THE U.K. BETWEEN 1960 AND 1970

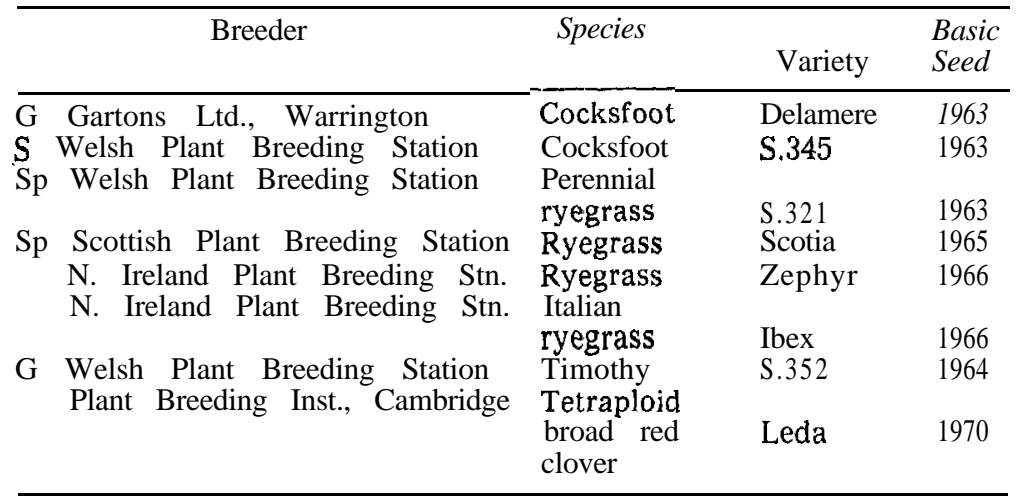

Key: $\mathrm{G}$ recommended for general use; $\mathrm{Sp}$ recommended for special use;

$\mathrm{S}$ recommended for special use but due to be withdrawn.

Large differences have been demonstrated in the response of different genotypes to fertilizer application (particularly nitrogen). But, even so, the yields of the new varieties are little different from those introduced twenty years ago and it would appear that natural variation does not offer much scope for further improvement. Perhaps the most important change has been the acceptance by the breeder that grasses need to be bred for specific farming requirements (e.g., grazing or cutting) and increased nutritive value and not primarily for adaptability and tolerance to indifferent management. 
With legumes the emphasis has been on breeding for resistance to disease. New tetraploid forms of broad red clover look particularly promising with regard to resistance against clover rot and need to be treated virtually as a new crop. The Plant Breeding Institute, Cambridge, have also produced a variety resistant to stem eelworm. Efforts to breed white clover that will grow in association with grass receiving heavy dressings of nitrogen and that is cut frequently, have not proved very successful.

\section{AGRONOMY AND SOIL SCIENCE}

Agronomists have been occupied mainly in research aimed at answering practical farming problems. The introduction of a routine in vitro method for the determination of digestibility (Tilley and Terry, 1963) has enabled them to study in much greater detail the changes in digestibility that occur as the crop ages and increases in yield. Thus they have been able to assess more precisely the energy available to the animal and the value of different species and varieties under different regimes of harvesting and for different animal production systems.

\section{Grass as a Break Crop in the Arable Rotation}

The importance of the grass as a break -crop has been thoroughly explored by several groups of workers in order to ascertain the effects of the added, organic matter on soil structure and nutrient supply (Clement, 1961). The conclusion seems to be that it is very difficult to measure in the laboratory the effects on soil structure that can be observed by eye in the field and that are accepted as being of much importance on many soils. The quantitative effect of the residual nitrogen on succeeding crops is much more easily measured and accounts for about $90 \%$ of the residual value of the sward when it is ploughed in (Williams et al., 1960; Cooke, 1967).

\section{W A T E R}

Despite the excess of rainfall in some parts of the country, water limits the growth of grass in many areas. For example, in the South-east and Midlands of England full irrigation will, on average, increase yield by 40 to $50 \%$ annually, the range being from no increase in yield in wet years to a two-and-a-half fold increase in dry years.

One of the most important practical developments has been the discovery by Garwood and Williams (1967) that 
the decrease in the growth of ryegrass during periods of restricted rainfall is not due to shortage of water per se, but to a local shortage in the top foot of the soil horizon that prevents the uptake of nitrogen. Drought conditions can therefore be overcome by applying much less water than would be required to bring the soil back to field capacity, as all that is required is sufficient water to enable the grass to take up nitrogen. In practice it has been found sufficient to apply about one-third of the water required for field capacity immediately after the fertilizer is added.

\section{NITROGEN}

The response of the grass crop to nitrogen has been studied very thoroughly by both official and commercial agronomists, and the dose-response curves for many practical situations seems to be well understood. Work continues in the field particularly with regard to the time and quantity of application in relation to harvest, and on the differences between the dose-response curves for grass cut for conservation and grass grazed by different types of stock. Under more controlled conditions in the glasshouse and field, attempts are being made to quantify some of the parts of the nitrogen cycle, particularly the nature of the losses due to denitrification and leaching (Grassland Research Institute, 1969; Agricultural Research Council, 1969).

\section{OTHER NUTRIENTS}

Much of the work on phosphorus and potassium during the last decade has centred on methods for determining the amounts of these elements that are available in different soils, and in understanding how they are held there (Beckett, 1964a, b; Salmon, 1964; Mattingley, 1965). Little practical importance has emerged except perhaps the likelihood that, in future, fertilizer practice in respect to potassium will be based increasingly on crop analyses. As the levels of yield rise with the increasing use of nitrogen, so the importance of minor elements is likely to increase and more work on these has been started.

\section{FORAGE QUALITY}

-Digestibilitiy

The development of the in vitro method as a routine technique for determining the digestibility of forages at 
the beginning of the 1960s helped workers in many fields of grassland research. It is now widely used in the U.K. as a criterion of selection by plant breeders for the evaluation of herbage varieties, and for the assessment of feed.

\section{T T A K}

The simple relationship between digestibility and voluntary intake postulated by Blaxter (1967) has been further explored by several workers and shown to vary with many intrinsic and extrinsic factors (Raymond, 1969). Legumes are known to have a higher intake, at the same digestibility than grasses. Osbourn (1967) has also shown differences between grass species and varieties and has developed the concept that this is due to differences in the composition of the digested component of the feed and, in particular, to the proportion of digestible "soluble" constituents to the digested fibre. If digestible fibre takes longer to be digested in the rumen than the digestible soluble components, then it will occupy more volume $X$ time in the rumen, and the intake of forages with a high proportion of digestible fibre should be lower. This hypothesis has been confirmed with several varieties [voluntary intake of Italian ryegrass is greater than perennial ryegrass (Grassland Research Institute, 1970a) and S.352 greater than S.51 timothy (Jones and Walters, 1969)] and suggests the usefulness in a breeding programme of selecting for higher pepsin-soluble constituents.

Extrinsic factors concerning the availability and method of presentation are usually more important than the intrinsic factors concerned with the chemical composition of the feed and are considered below in relation to the stall feeding of ensilage and dehydrated forage. They are also important under grazing conditions where high grazing intensity, fouling, excessive rain, etc., may limit intake on swards of high potential voluntary intake characteristics. Studies on selective grazing (Tayler and Deriaz, 1963) suggest that restricted intake, rather than low feed digestibility, may be the main factor reducing animal production at high grazing intensity. Further critical examination of the faecal index techniques has shown systematic errors in translating indoor relationships to the field and these largely invalidate the method. Other methods based on the use of oesophageal fistulated animals and combined with chemical and digestibility measurements on extrusa have helped, but techniques are still not adequate (Langlands, 1967). 


\section{SILAGE}

The low voluntary intake of silage, as compared with the fresh or dried forage from which it is made, has received much attention. The advantages of reducing the moisture content of grass before it is ensiled is well established (Moore et al., 1960) and the research results have been translated into practical recommendations. In the British climate such weather-dependent operations as field drying are not universally acceptable and attention is being given to techniques for overcoming the low intake characteristics of silage made from wet forage (McLeod et al., 1970).

This low intake of "wet" silages seems to be due to (1) the concentration of organic acids and the resulting low $\mathrm{pH}$, and (2) the presence of free ammonia arising from the breakdown of nitrogenous constituents. The latter can fortunately be overcome by good silage-making techniques and the use of forages with a low protein content. A low $\mathrm{pH}$ is, however, one of the requirements of a stable silage.

In practice the low voluntary intake of silage can be overcome by partially neutralizing the silage before feeding (McLeod et al., loc. cit.) or by feeding in mixed rations with feeds such as cereals or dehydrated grass (Grassland Research Institute, 1969). The special problems of "wet" silage can be mitigated by the addition of sterilants such as formic acid before the forage is ensiled. This technique, which is used extensively in Norway, has been virtually untested in Europe until the last year or two. Its recent popularity in Britain has been associated with the introduction of a simple method of spraying the acid on to the cut crop at the time of harvesting. Results at G.R.I. (Grassland Research Institute, 1970a) have confirmed that "silage made in this way has a higher intake than silage made from untreated material so long as the amount of ammonia formed during the fermentation is also reduced.

Interesting possibilities now exist for further improvements using formaldehyde as an additive. Such techniques, together with improvements to keep the fermentation completely anaerobic, should enable harvesting to proceed even when the water content of the crop is greater than $70 \%$, and thus be practically independent of weather.

\section{DehydRATED ForAge}

Work on dehydrated forages has increased considerably during the last four years. Much of it has been concerned 
with the effects of particle size and form of package (pellet, cob or wafer) on the food conversion efficiency of the feed by different types of animals. In general, it seems that intake rises and digestibility decreases as the fineness of the particle size is increased but that, on balance, the efficiency of food conversion increases with fineness of grinding (Lonsdale and Tayler, 1969). Such milled and pelleted dried grass has interesting properties when fed as a supplement to silage (high water content) as the dry matter intake of a half-and-half mix of silage and dried grass pellets can be as high as the intake of dry matter of the dried grass alone (Grassland Research Institute, 1969). Dried forage with a digestibility of $65 \%$ (dig. of DM) and a crude protein of $16 \frac{1}{2} \%$ has been shown in several experiments with dairy cows to have a feeding value "about four-fifths that of commercial "dairy nuts" (Connell and Jones, 1968). It is of special interest as a high protein feed for addition to low protein silages (e.g., maize) which are much easier to make than silages from high protein crops (e.g., red clover).

\section{ANIMAL NUTRITION}

The more fundamental studies on animal nutrition now being undertaken in several laboratories in Britain may, in the future, have a marked effect on the way in which forages are fed.

(1) The Agricultural Research Council system of assessing the nutritive value of feeds relies on net energies calculated from digestibility data (Agricultural Research Council, 1965). Recent work has demonstrated discrepancies in such a method that need to be clarified. For example:

(a) Grass harvested in the autumn can have a much lower net energy value than the same grass cut in the spring, although of the same digestibility (K. L. Blaxter, F. W. Wainman, P. J. S. Dewey, unpubl. data).

(b) The reduced digestibility of milled dried forages noted is not associated with a reduction in net energy.

(2) An understanding of the reasons why forages processed in different ways are utilized with varying efficiency may lead to more rational evaluation of the feed value of forages in mixed diets and, their better utilization. For example, rumen $\mathrm{pH}$ shows wide diurnal variations and is reduced when cereals are fed. 
but as the rumen $\mathrm{pH}$ decreases both the rate and ex. tent of fibre digestion also decrease (Terry et al., 1969). Thus cereals create conditions within the rumen which are sub-optimum for the digestion of forages. This may partly explain the rapid decrease in hay intake when barley is fed and the poor response to barley supplements fed to grazing livestock. The proportion of volatile fatty acids produced in the rumen also seems to be related to $\mathrm{pH}$, propionic and lactic increasing and acetic decreasing as $\mathrm{pH}$ decreases. Thus there is the possibility of programmed feeding to establish optimum conditions for the utilization of forages.

(3) Processing of forages also affects the pattern of their digestion. The effect of milling on digestibility has been mentioned. This is mainly due to the decreased digestion of fibre in the rumen. The drying process itself also alters the solubility of the proteins in forage and increases the quantity of amino acids entering and being absorbed from the hind tract (Thomson, 1969).

\section{ECOLOGY}

Grassland research is essentially a study of the interrelationships between the crop, the environment in which it grows, and the animals that eat it, as well as the humans. On the whole, therefore, it is an ecological exercise, and some of the most important developments that are taking place in British grassland research are those associated with the emergence of a new ecology concerned with the quantification of the inter-related factors in the grassland ecosystem and the utilization of the information so gained to simulate the real situation by the construction of mathematical models. These simulation models aid in the collation of existing data, indicate the most relevant gaps in our knowledge, and lead to the construction and testing of more worthwhile animal production systems based on grass and forage (Morley and Spedding, 1968; Jones et al., 1968).

At the beginning of the decade, this holistic approach to grassland research was only just emerging and there was still a marked gap between, on the one hand, nutritional and physiological studies on animals indoors, and, on the other hand, field investigations on animal production. The indoor nutritional experiments were reasonably well controlled, albeit in somewhat artificial conditions, but they tended to involve a rather narrow range of animals 
that were not agriculturally the most important. The field experiments struggled to be relevant, lacked control and were difficult to interpret because essential data (rate of grass growth, food intake by animals) were not collected.

Spedding (1969) was perhaps the first fully to appreciate that, at all levels, the significance of a single component cannot be adequately stated without reference to (and thus knowledge of) the system of which it is a part. With his detailed study of the sheep and the factors affecting food conversion efficiency the year round in fat lamb production systems, Spedding showed how the gap between the indoor nutritional and the outdoor field studies could be bridged. An analysis of the animal populations to define the kinds of animal and their needs at different periods of their lives led him on to an understanding of how the total food used in the system was distributed in time and between animals at different phases of pregnancy, maintenance, growth and lactation. These studies required the same degree of control as was needed in the nutritional studies. They, therefore, had to be done indoors and required a substantial development in accommodation for keeping animals indoors, in order that ewes and lambs, for example, could thrive and still allow measurement of food consumption, etc. They also required the development of special techniques for manipulating factors such as reproductive rate and of artificial rearing of lambs (Newton and Betts, 1966, 1968; Penning, 1967).

Such studies have now put Spedding and his colleagues in the position where reasonable mathematical models of sheep production can be constructed and where they can return to the field not only to test the results of their work expressed as systems, but also to improve scientific experimentation in the field (Grassland Research Institute, 1969) .

The same approach is now being developed at Hurley with beef suckler cows (Spedding, 1969) and to the "sward" side of the grazing interaction. In the latter, the main component parts of the grazing situation are separated for individual study. The current experiments deal with the separate effects of the presence of the grazing animali.e., treading, fouling with excreta and defoliation (Grassland Research Institute, 1969).

The complexity of the sward situation, however, is no greater than that of the animal population and certainly no greater than that of the farming systems to which the results have to apply. It is not surprising, therefore, that the inevitability of this complexity has led grassland re- 
search workers to turn to the computer and the techniques of simulation and model building. Considerable progress has been made in the last three years (Grassland Research Institute, 1969, 1970a, b) .

Even so, it is still possible to put the separate pieces of information about the sward, the animal and the environment together to make viable animal production systems without the aid of these more refined techniques. A good example of such a system developed by research workers is the "Intensive System of Beef Production from Grassland using Autumn-born Calves from the Dairy Herd" (Joint Beef Production Committee, 1967).

\section{THE FUTURE}

The next ten years are not going to be as easy for agricultural research as the last. The general impression at the beginning of the sixties was that the British farmer was feather-bedded. At the beginning of the seventies it is the research worker who is believed to be in the feather bed and funds for research will be much harder to come by in the future than in the past. If Britain enters the European Economic Community, this will increase the importance of home-grown grass and forage in our agricultural economy, and research in this area will become more important if the Government pursue 'their agricultural expansionist policy. During the past five years it has been the single species sown swards that have received the most attention from agronomists. However, it is the 10 million acres of "permanent" lowland pasture that have the most to offer in the way of increased output, and that have been neglected by the grassland agronomist. It is now time to return to these applied problems of permanent pasture armed with a much greater knowledge, not only of the biology of the situation, but also of how to tackle them. The requirement is for a research strategy based upon a systems approach and a detailed assessment of the whole situation, biological, economic and social, before embarking on analytical research in any of these areas. Grassland research, when it has to deal with natural pastures and rough grazings, must, in our over-populated islands, also deal with the sociological problems of recreation. It is to be hoped that those in authority will realize that one of the most important problems requiring attention is how to combine extensive agriculture based on the grazing animal with the recreational needs of our people. 


\section{REFERENCES}

Agricultural Research Council, 1965: The Nutrient Requirements of Farm Livestock. No. 2. Ruminants. H.M.S.O., London.

1969: A. Rep. Agric. Res. Counc. Lctcombe Lab. 1968: 49-50. Anon., 1969: Annual Review and Determination of Guarantees. Cmd. 3965. H.M.S.O., London.

Anslow, R. C., 1966: Light interception and growth rate of a perennial ryegrass sward. Proc. 9th int. Grassld Congr.: 403-5

Ashton, J., 1963: National Agricultural Advisory Service/Animal Feeding Stuffs Industry - Joint Conference. University of Keele.

Bcckett, P. H. T., 1964a: Studies on soil potassium. I. Confirmation of the ratio law: measurement of potassium potential. J. Soil Sci, 15: $1-8$.

1964b: Studies on soil potassium. II. The immediate Q/1 relations of labile potassium in the soil. J. Soil Sci., 15: 9-23.

Blaxter, K. L., 1967: The Energy Metabolism of Ruminants. Hutchinson, London.

Clement, C. R., 1961: Benefit of leys-structural improvement or nitrogen reserves. J. Br. G rassld Soc., 16: 194-200.

Connell J.; Jones, J. G. W., 1968: The dried grass cube as a production concentrate for the dairy cow. Anim. Prod., 10; 231.

Cooke, G. W., 1967: Advice on using fertilizers: Il R. agric. Soc., 128: $107-24$.

Garwood, E. A.; Williams, T. E., 1967: Growth, water use and nutrient uptake from the subsoil by grass swards. J. agric. Sci., Camb., 69: $125-30$.

Grassland Research Institute 1969: A. Rep. Grassid Res. Inst., 1968: 34, 71-2.

1970a: A. Rep. Grassid Res. Inst. 1969: (in press).

-- 1970b: Proc. Symp. on U se of Models in Agric. and Biol. Res. Feb., 1969 (in press).

Hatch, M. D.; Slack, C. R., 1966: Photosynthesis by sugarcane leaves (a new carboxylation reaction and the pathway of sugar formation). Biochcm. J., 101: 103-11.

Hatch, M. D.; Slack, C. R.; Johnson, H. S., 1967: Further studies on a new pathway of photosynthetic carbon dioxide fixation in sugarcane and its occurrence in other plant species. Biochem. J., 102: 417-22.

Joint Beef Production Committee, 1967: An intensive system of beef production from grassland using autumn-born calves from the dairy herd. Handbook No. 1. Meat and Livestock Commission, London.

Jones, D. I. H.; Walters, R. J. K., 1969: Varietal variations in nutritive characteristics. Occ. Symp. Br. Grassld Soc. No. 5: 36-43.

Jones, J. G. W.; Radford, P. J.; Young, N. E., 1968: Simulation of the growth of the grazing lamb. Anim. Prod., 10: 242-3.

Langer, R. H. M., 1956: Growth and nutrition of timothy (Phleum pratense). I. The life history of individual tillers. Ann. appl. Biol., 44: 166-87.

1957: The growth and nutrition of timothy (Phleum pratense). II. Growth of plant in relation to tiller development. Ann. appl. Biol., 45: 528-41. 
Langlands, J. P., 1967: Studies on the nutritive value of the diet selected by grazing sheep. III. A comparison of the oesophageal fistula and faecal index techniques for the indirect determination of digestibility. Anim. Prod., 9: 325-31.

Lonsdale, C. R.; Tayler, J. C., 1969: The effect of stage of maturity of artificially dried grass and method of processing on growth of young Cattle. Abstract in Anim. Prod., 11 (2): 273.

McDonald, P.; Watson, S. J.; Whittenbury, R., 1966: The principles of ensilage. Z. Tierphysiol. Tierernahr. Futtermettalk., 21: 104-10.

McLeod, D. S.; Wilkins, R. J.; Raymond, W. F., 1970: The voluntary intake by sheep and cattle of silages differing in free acid content (in press).

Mattingley, G. E. G., 1965: The influence of intensity and capacity factors on the durability of soil phosphate. Chapter in Soil Phosphorus, Tech. Bull. No. 13. Ministry of Agriculture, Fisheries and Food. H.M.S.O., London.

Milk Marketing Board of England and Wales, 1970: Low Cost Production. Handbook Article No, 84.

Monteith, J. L., 1965: Light distribution and photosynthesis in field crops. Ann. Bot. N.S., 29: 131, 17-37.

Moore, L. A.; Thomas, J. W.; Sykes, J. F., 1960: Grass and legume silage for cows. Proc. 8th int. Grassld Congr., Reading: 701-4.

Morley, F. H. W; Spedding, C. R. W., 1968: Agricultural systems and grazing experiments. Herb. Abstr., 38: 279-87.

National Economic Development Committee for the Agricultural Industry, 1968: Agriculture's Import Saving Role -Report by the Economic Development Committee. H.M.S.O., London.

Newton, J. E.; Betts, J. E., 1966: Factors affecting litter size in the Scotch Half-bred ewe. 1. Treatment with PMS and progesterone. J. Reprod. Fertil., 12: 167-75..

1968: Factors affecting litter size in the Scotch Half-bred ewe. II. Superovulation- and synchronisation of oestrus. J. Reprod. Fertil., 17: 485-93.

Osbourn, D. F., 1967: Forage Conservation. Occ. Symp. Br. Grassld Soc. No. 3: 20-28.

Patel, A. S.; Cooper, J. P., 1961: The influence of seasonal changer; in light energy on leaf and tiller development in ryegrass, timothy and meadow fescue. J. Br. Grassld SOC., 16: 299-308.

Penning, P. D., 1967: A. Rep. Grassld Res. Inst., 1966: 86-92.

Raymond, W. F., 1969: Components in the nutritive value of forag əs. "Symposium: Forage Economics - Quality." A m. Soc. Agron. Spec. Publ. 13: 25-35.

Robson, M. J., 1967: A comparison of British and North African varieties of tall fescue (Festuca arundinacea). 1. Leaf growth during the winter and the effect on it of temperature and day length. J. appl. Ecol., 4: 475-84.

1968: A comparison of British and North African varieties of tall fescue (Festuca arundinacea). IV. Tiller production in single plants. J. appl. Ecol, 5: 431-43.

Ryle, G. J. A., 1967: Growth rates in Lolium temulentum as influenced by previous regimes of light energy. Nature, Lond., 213: $309-11$. 
1970: Assimilate partitioning in an annual and a perennial grass (in press)

Salmon, R. C., 1964: Cation activity ratios in equilibrium soil solutions and the availability of magnesium. Soil Sci., 98: 213-21.

Spedding, C. R. W., 1969: The agricultural ecology of grassland. The Middleton Memorial Lecture. Agric. Progress, 44: 7-23.

Tayler, J. C.; Deriaz, R. E., 1963: The use of rumen fistulated steers in the direct detemination of nutritive value of ingested herbage in grazing experiments. J. Br. Grassld Soc., 18: 29-38.

Terry, R. A.; Tilley, J. M. A.; Outen, G. E., 1969: Effect of pH on cellulose digestion under in vitro conditions. J. Sci. Fd. Agric.. 20: $317-20$.

Thomson, D. J., 1969: Effects of drying grass on sites of its digestion in sheep. Proc. Nutrition Soc., 28 (1) : 26A.

Tilley, J. M. A.; Terry, R. A., 1963: A two-stage technique for the in vitro digestion of forage crops. J. Br. Grassld Soc., 18: 104-17.

Watson, D. J., 1952: The physiological basis of variation in yield. Adv. Agron., 4: 101-45. 1-9.

Williams, T. E.; Clement, C. R.; Heard, A. J., 1960: Soil nitrogen status of leys and subsequent wheat yields. Proc. 8th int. Grassld Congr.: 237-41.

de Wit, C. T., 1965: Photosynthesis of leaf canopies. Agric. Res. Rep, No. 663, Centre for Agricultural Publications and Documentations, Wageningen, Netherlands.

\section{DISCUSSION}

Asked if there was a proportional increase in dry matter yields per unit of nitrogen as $\mathrm{N}$ levels increased, Woodford replied that the yield of grass was linear to $\mathrm{N}$ applications up to 300 units in many instances. This, of course, referred to straight grass pasiures. In grass/clover swards, it was not possible to maintain the clover when more than 200 units of $\mathrm{N}$ were applied. The nitrogen was usually applied as 100 units in spring and then 40 to 50 units after each grazing.

To an inquiry from Heath (U.S.A.) as to whether he could identify gaps for further study as a result of the model simulation approach, Woodford said there were insufficient data on the respiration and physiological aspects to build a model for ryegrass growth and so they had to go into the field for data. It was also difficult in aspects of animal nutrition to build models because of the lack of data. It was absolutely necessary to know the physiological responses of the animal at all stages of its development.

Asked to comment on grass drying and its cost, Woodford stated that there was improved machinery available which gave high-temperature flash drying at $1,000^{\circ} \mathbf{C}$. The price of an economic set-up in Britain was $£ 70,000$ and in most cases some Government assistance was required. Costs were in the vicinity of $£ 18$ per ton. 